\title{
Expression of inducible nitric oxide synthase activity in human colon epithelial cells: modulation by $\mathrm{T}$ lymphocyte derived cytokines
}

\author{
G Kolios, N Rooney, C T Murphy, D A F Robertson, J Westwick
}

\begin{abstract}
Background-Nitric oxide (NO) synthesis and inducible nitric oxide synthase (iNOS) expression are increased in colonic biopsy specimens from patients with ulcerative colitis, but the cellular source of NO production is not known.

Aims-To examine the distribution of iNOS in human colonic mucosa and to explore the ability of $T$ lymphocyte derived cytokines to regulate iNOS expression and activity in human colonic epithelial cells.
\end{abstract}

Methods-iNOS expression was examined using immunohistochemistry in colonic biopsy samples from 12 patients with ulcerative colitis and three with infectious colitis and compared with 10 normal controls. In vitro iNOS expression and activity were determined in HT-29 cell cultures; nitrite levels were measured using a fluorescent substrate, iNOS mRNA expression by northern blot analysis, and iNOS protein expression by western blot analysis.

Results-No iNOS expression was detected (10 of 10) in non-inflamed mucosa derived from normal controls. In 11 of 12 cases of newly diagnosed ulcerative colitis, iNOS protein was expressed in the epithelial cells, while no other positive cells were found in the lamina propria. Similar iNOS labelling was found in colonic biopsy samples from patients with infectious colitis in the acute phase, but when re-examined in samples from patients in total remission, no iNOS staining was observed. Both interleukin (IL)-13 and IL-4, but not IL-10, are potent inhibitors of iNOS expression and activity induced by an optimal combination of cytokines, namely IL-1 $\alpha$, tumour necrosis factor $\alpha$ and interferon $\gamma$.

Conclusions-The data suggest that the epithelium is the major source of iNOS activity in ulcerative colitis and that IL-13 and IL-4 may act as intrinsic regulators of NO generation in intestinal inflammation. (Gut 1998;43:56-63)

Keywords: interleukin 13; nitric oxide; inducible nitric oxide synthase; colonic epithelial cells; ulcerative colitis

Correspondence to: Professor John Westwick, School of Pharmacy and Pharmacology, University of Bath, Claverton Down, Bath BA2 7AY, United Kingdom.

Accepted for publication 19 January 1998
Nitric oxide (NO) is produced by a variety of cell types and it is an important molecular messenger with many physiological roles in the cardiovascular, neurological, and immune sys- tems. It is synthesised by a family of enzymes, the nitric oxide synthases (NOS), which convert the amino acid L-arginine into L-citrulline and NO. ${ }^{12}$ Two of the NOS are continuously present and are termed constitutive. $^{3-5}$ These two isoforms require calcium and calmodulin, produce small amounts of NO, and are involved in homoeostatic processes. ${ }^{6}$ A third isoform, which is calcium and calmodulin independent, is expressed after induction by certain cytokines, microbes, or microbial products, and is thus called inducible NOS (iNOS) ${ }^{7}$; it is responsible for the major $\mathrm{NO}$ production in tissues. ${ }^{18} \mathrm{NO}$ is produced at many sites in the gastrointestinal tract and is believed to take part in physiological and pathological events. ${ }^{9}$ Studies in patients with inflammatory bowel disease (IBD) have shown a marked increase in NO synthesis ${ }^{10} 11$ and NOS activity ${ }^{12}$ in the inflamed mucosa from patients with ulcerative colitis (UC) compared with uninflamed controls, but the cellular source of $\mathrm{NO}$ in the mucosa is not known. However, there is increasing evidence to suggest that the colonic epithelium is the source of NO and that it is highly regulated by cytokines. For example, we have recently demonstrated that stimulation with a "cocktail" of proinflammatory cytokines induces iNOS mRNA expression and nitrite generation in the human colonic carcinoma cell line HT-29.13

In the present study we investigated, using a monospecific iNOS antibody, iNOS expression in the mucosa of patients with UC and infectious colitis, and compared the results with those obtained for normal controls. In addition, we explored the role of $\mathrm{T}$ cell derived cytokines in the regulation of epithelial iNOS expression and activity, as a specific population of lymphocytes and their cytokines are present in IBD lesions. ${ }^{14}$ Three $\mathrm{T}$ cell derived cytokines, interleukin (IL)-13, IL-4, and IL-10, have all been proposed as anti-inflammatory cytokines. For example, IL-13 is a potent suppressor of cytokine and chemokine expression by activated monocytes and macrophages ${ }^{15} 16$ and endothelial cells. ${ }^{17}$ Similar biological activities are also displayed by IL-4, while IL-4 alone has an effect on human T cells. ${ }^{16} \mathrm{IL}-10$ is produced by a variety of cells including activated human $\mathrm{T}$ cells, and it is also a potent suppressor of cytokine and chemokine generation by activated monocytes/macrophages ${ }^{18} 19$ and polymorphonuclear cells. ${ }^{20}$ These three $\mathrm{T}$ cell derived cytokines have been found in colonic mucosa from patients with IBD, ${ }^{21-24}$ but investigations into their production in association 
with this disease have so far been inconclusive. ${ }^{25}$ IL-4, IL-10, and IL-13 modulate cytokine production in UC and Crohn's disease, ${ }^{26}$ and it has been suggested that changes in their production may be associated with the pathogenesis of IBD.$^{27}$ In addition, the role of IL-10 as negative regulator of colonic inflammation is suggested by the "chronic enterocolitis" phenotype expressed in IL-10 deficient mice. ${ }^{28} 29$

\section{Materials and methods \\ MATERIALS}

Recombinant human (rh)IL-1 $\alpha$ (specificity $5 \times$ $10^{7} \mathrm{U} / \mathrm{mg}$ ) and tumour necrosis factor $\alpha$ $(\mathrm{TNF}-\alpha)$ (specificity $6 \times 10^{7} \mathrm{U} / \mathrm{mg}$ ) were gifts from Glaxo (Greenford, Middx, UK) and Bayer (Slough, Berks, UK) respectively. Recombinant human interferon $\gamma$ (rhIFN- $\gamma$ ) (specificity $>2.0 \times 10^{7} \mathrm{U} / \mathrm{mg}$ ) was purchased from Boehringer-Mannheim, Lewes, Sussex, UK. rhIL-13 was purified from culture supernatants of stable transfected $\mathrm{CHO}$ cells ${ }^{15}$ and generously provided by Dr A Minty (Sanofi, Recherche, Labege, France). rhIL-10 (specificity $1 \times 10^{7} \mathrm{U} / \mathrm{ml}$ ) was kindly donated by $\mathrm{Dr} \mathrm{K}$ W Moore (DNAX, Palo Alto, CA, USA). rhIL-4 (specificity $>1 \times 10^{7} \mathrm{U} / \mathrm{mg}$ ) was purchased from Genzyme. Sodium nitrite and 2,3-diaminonaphthalene were from Sigma Chemical and Lancaster Synthesis Ltd respectively. The digoxigenin chemiluminescent detection kit for northern blotting came from Boehringer-Mannheim. 5'-Digoxigenin labelled probe for iNOS was a cocktail containing three antisense 30-mer oligonucleotides purchased from R \& D Systems (Abingdon, Oxon, UK). Dr J R Weinder and colleagues at Merck Research Laboratories, Rahway, NJ, USA characterised and generously provided a rabbit anti-iNOS affinity purified immunoglobulin G designated NO-53, which was raised against the last seven C-terminal amino acids of human iNOS and does not cross react with the constitutive NOS isoform..$^{30}$ The ABC complex and the 3,3'-diaminobenzidine peroxidase substrate tablets set were from Dako and Sigma respectively.

CELL CULTURES

The HT-29 cell line was purchased from the European Collection of Animal Cell Cultures. Cell cultures were maintained in McCoy's 5A medium (Gibco) supplemented with 10\% fetal calf serum, penicillin/streptomycin $(10 \mathrm{U} / \mathrm{ml}$ and $10 \mu \mathrm{g} / \mathrm{ml})$ and Fungizone $(0.5 \mu \mathrm{g} / \mathrm{ml})$ (complete medium), incubated at $37^{\circ} \mathrm{C}$ in an atmosphere of $5 \% \mathrm{CO}_{2}$, and passaged weekly. For experiments, HT-29 cells were seeded at $(2-3) \times 10^{4} / \mathrm{cm}^{2}$ in six-well plates (Nunc, UK) in complete medium and incubated at $37^{\circ} \mathrm{C}$ in $5 \% \mathrm{CO}_{2}$ until confluent. Confluent cell cultures were treated with the appropriate concentrations of stimuli in medium without fetal calf serum and incubated as above.

FLUORIMETRIC ASSAY OF NITRITE

NO production by HT-29 cells was determined by measuring in culture supernatants the stable end product nitrite. Nitrite was measured using the fluorimetric assay described by Misko et $a l .{ }^{31}$ This assay is based on the reaction of nitrite with 2,3-diaminonaphthalene to form the fluorescent product 1-(H)-naphthotriazole. The samples were measured using a PTI dual wavelength spectrophotofluorimeter (excitation at $365 \mathrm{~nm}$ and emission at $405 \mathrm{~nm}$ ), as previously described. ${ }^{13}$ The sensitivity of the assay was $10 \mathrm{nM}$.

\section{NORTHERN BLOT ANALYSIS}

Total cellular RNA from HT-29 cells was isolated as previously described. ${ }^{13}{ }^{32}$ Total RNA was separated by electrophoresis using formaldehyde $/ 1 \%$ agarose gels and transferred overnight to nylon membrane (BoehringerMannheim) by capillary blotting. The blots were hybridised overnight at $60^{\circ} \mathrm{C}$ with digoxigenin labelled oligonucleotide probes (10 $\mathrm{ng} / \mathrm{ml}$ ) for iNOS. Bound probes were detected using anti-digoxigenin Fab fragments conjugated to alkaline phosphatase with lumigen PPD (Boehringer-Mannheim) as the chemiluminescent substrate. Specific iNOS mRNA was quantified by laser densitometry. Equivalent amounts of total RNA load per gel lane were assessed by monitoring $18 \mathrm{~S}$ and $28 \mathrm{~S}$ RNA.

\section{WESTERN BLOT ANALYSIS}

At predetermined times after stimulation, HT-29 monolayers were scraped into Laemmli SDS reducing gel sample buffer which contained $5 \mu \mathrm{g} / \mathrm{ml}$ carboxypeptidase inhibitor. ${ }^{33}$ Solubilised proteins were separated by sodium dodecyl sulphate/polyacrylamide gel electrophoresis on $7 \%$ gels and transferred to a nitrocellulose membrane. Membranes were incubated for one hour with rabbit anti-human iNOS antibody (NO-53) diluted 1:40 000 in phosphate buffered saline/Tris. Specific binding was obtained using alkaline phosphatase conjugated sheep anti-rabbit immunoglobulin with BCIP substrate (Sigma) as chromagen. All incubations and washes were carried out at room temperature with gentle shaking.

\section{PATIENTS}

Colonic biopsy specimens were selected from patients who had been diagnosed at the Royal United Hospital, Bath. The patient groups included active UC $(\mathrm{n}=12$, nine men and three women, median age 42 years, range 24-59), infectious colitis $(n=3$, three men, median age 41 years, range 29-56), and controls ( $\mathrm{n}=10$, six men and four women, median age 64 years, range 26-84). All patients with UC were newly diagnosed with moderate to severe disease activity at the time of colonoscopy. All patients were examined before treatment, and biopsy samples were taken from the areas of greatest inflammation. Routine histological examination of these specimens showed ulceration, mucin depletion, deformation of the glands, crypt abscesses, and inflammatory cell infiltration of the lamina propria. Patients with infectious colitis, caused by salmonellosis, were examined, and biopsy specimens were taken before treatment and when the patients were in total remission after 
treatment. Biopsy samples of normal bowel mucosa from patients with diverticular disease $(n=2)$ and colon adenocarcinoma $(n=6)$ and from normal individuals $(\mathrm{n}=2)$ were used as controls. On routine histological examination, these samples had normal numbers of goblet cells and did not show any inflammatory infiltration of the lamina propria.

IMMUNOHISTOCHEMISTRY

Polyclonal rabbit antibody against the C-terminal sequence of human iNOS was used in an avidin/biotin method to demonstrate the presence of iNOS. Colonic biopsy samples that had been fixed in formalin and embedded in paraffin were mounted on 3-aminopropyltriethoxysilane coated slides. The mounted slides were incubated for one hour with rabbit anti-human iNOS antibody (NO53), diluted 1:1000. Gills haematoxylin was used as a counterstain. Blocking experiments were carried out by adding the immunogenic peptide at a concentration of $150 \mathrm{nM}$ to the working dilution of anti-iNOS antibody.
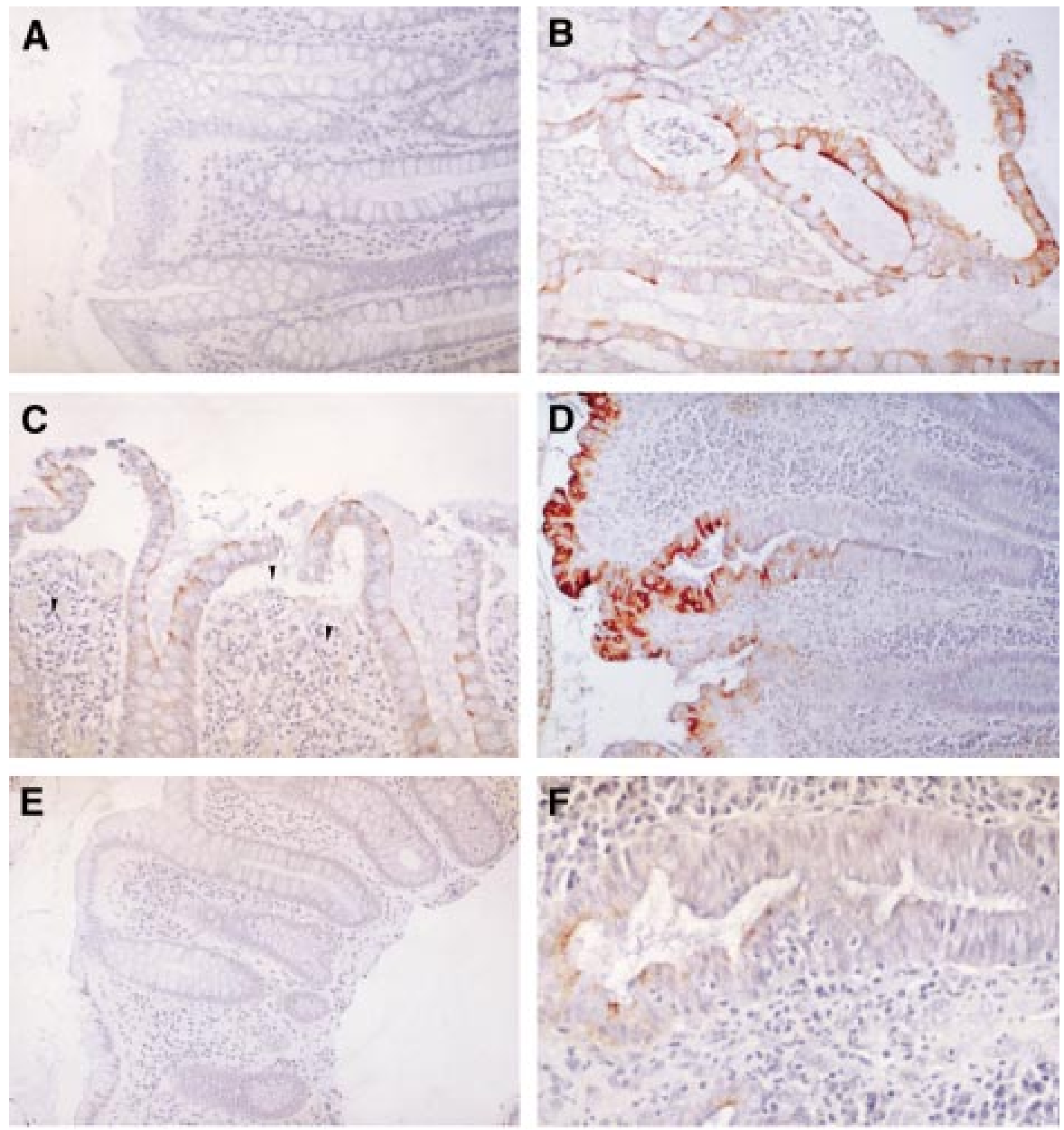

Figure 1 All sections were stained with anti-human inducible nitric oxide synthase (iNOS) antibody (NO-53) using avidin/biotin peroxidase. (A) Normal bowel with no detection of $i$ NOS. Original magnification $\times 100$. (B) Ulcerative colitis (UC) with staining of superficial section of crypt and surface epithelium. Original magnification $\times 100$. (C) Another UC case showing similar staining; iNOS labelling is located at the apical part of the epithelial cells, in close association with neutrophil infiltration of the lamina propria (arrowheads). Original magnification $\times 100$. (D) Acute infectious colitis with staining of the superficial section of crypt and surface epithelium. Original magnification $\times 100$. (E) Sample from the same patient after recovery, with resolution of iNOS expression. Original magnification $\times 50$. (F) Same section as (D) using primary antibody preabsorbed with immunogenic peptide. Original magnification $\times 250$. 


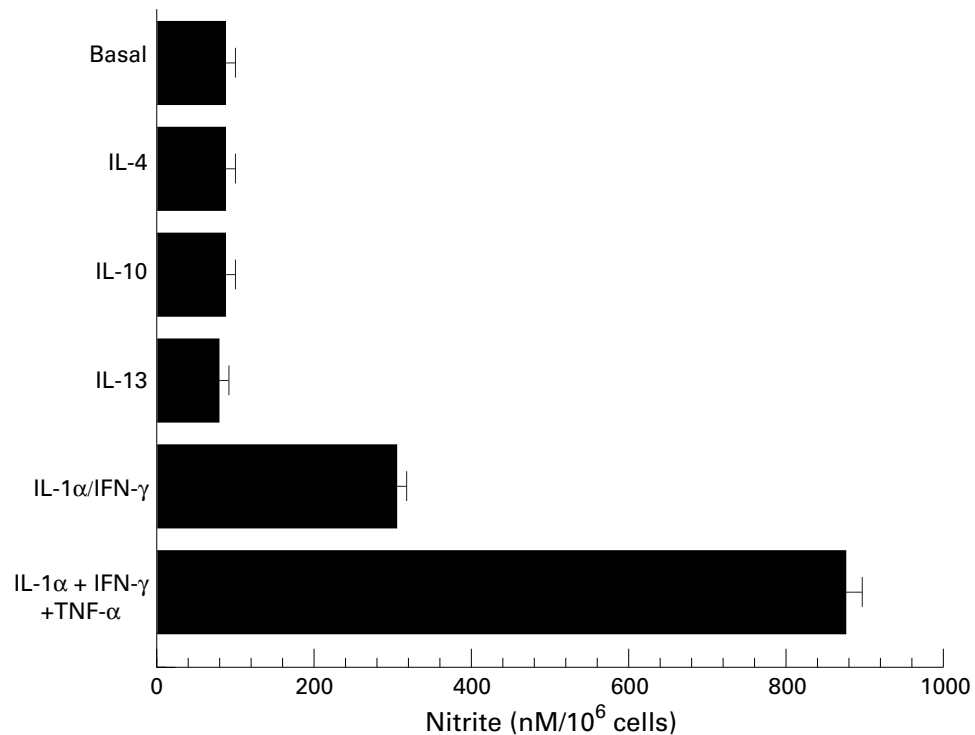

Figure 2 Nitrite production by HT-29 cells after treatment with cytokines. Confluent monolayers of HT-29 cells were treated with interleukin (IL)-13 (30 ng/ml), IL-4 (30 $\mathrm{ng} / \mathrm{ml}), I L-10(30 \mathrm{ng} / \mathrm{ml}), I L-1 a(10 \mathrm{ng} / \mathrm{ml}) /$ interferon $\gamma(I F N-\gamma)(300 \mathrm{U} / \mathrm{ml})$ or $I L-1 a$ $(10 \mathrm{ng} / \mathrm{ml}) / \mathrm{IFN}-\gamma(300 \mathrm{U} / \mathrm{ml}) /$ tumour necrosis factor a (TNF-a) $(100 \mathrm{ng} / \mathrm{ml})$, and after 48 hours incubation at $37^{\circ} \mathrm{C}$ nitrite levels were determined in supernatants, using a fluorescent substrate with a $10 \mathrm{nM}$ level of detection. Basal is the amount of nitrite produced by HT-29 cells in the absence of added cytokines. Results are expressed as means (SEM) from three separate experiments.

\section{STATISTICAL ANALYSIS}

Statistical significance was assessed by two way analysis of variance followed by Dunnett's test for multiple comparison with controls. Data are expressed as means (SEM) from three experiments. Triplicate determinations were performed in each experiment. $p \leqslant 0.05$ was taken as the criterion for a significant difference.

\section{Results}

IMMUNOHISTOCHEMISTRY

No iNOS expression was detected in the normal non-inflamed mucosa (10 of 10 cases) derived from patients with diverticular disease and colon adenocarcinoma and healthy individuals (fig 1A). In 11 of 12 cases of UC the

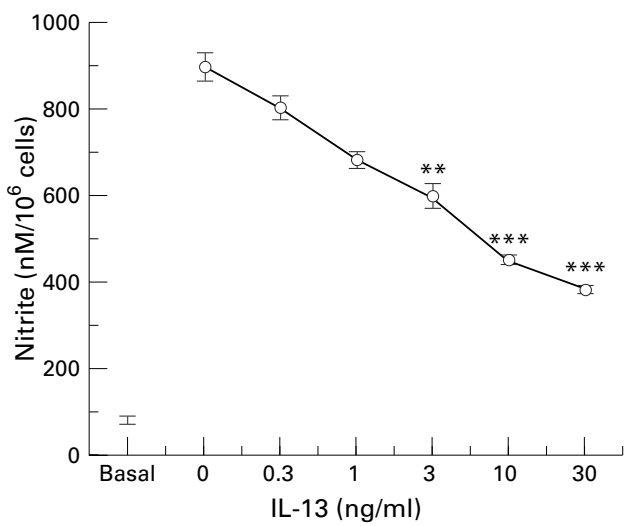

Figure 3 Nitrite production by HT-29 cells after treatment with interleukin (IL)-1a (10 $\mathrm{ng} / \mathrm{ml}) /$ interferon $\gamma(I F N-\gamma)$ $(300 \mathrm{U} / \mathrm{ml}) /$ tumour necrosis factor $(T N F-a)(100 \mathrm{ng} / \mathrm{ml})$ in the presence of increasing concentrations of $I L-13$.

Proinflammatory cytokines were added after one hour of pretreatment with IL-13, and nitrite levels were determined in supernatants after 24 hours incubation at $37^{\circ} \mathrm{C}$. Each point represents the mean (SEM) from three separate experiments. ${ }^{\star \star} p<0.01,{ }^{\star \star *} p<0.001$ compared with positive control response (no IL-13).

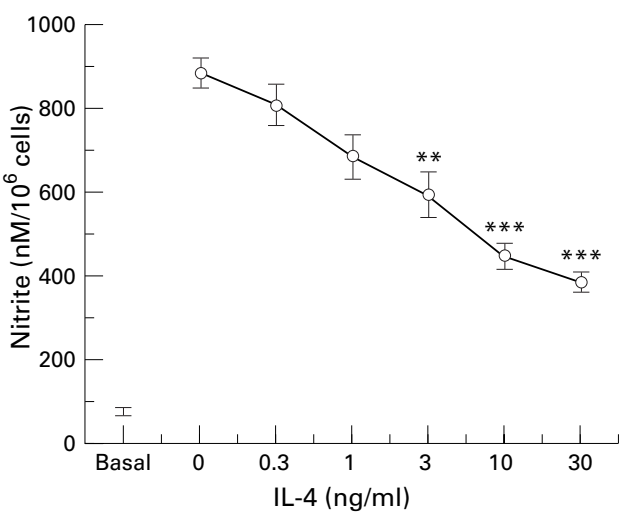

Figure 4 Nitrite production by HT-29 cells after treatment with interleukin (IL)-1a (10 $\mathrm{ng} / \mathrm{ml})$ /interferon $\gamma(I F N-\gamma)$ $(300 \mathrm{U} / \mathrm{ml}) /$ tumour necrosis factor a $(T N F-a)$ (100 $\mathrm{ng} / \mathrm{ml}$ ) in the presence of increasing concentrations of IL-4. Proinflammatory cytokines were added after one hour of pretreatment with IL-4, and nitrite levels were determined in supernatants after 24 hours incubation at $37^{\circ} \mathrm{C}$. Each point represents the mean (SEM) from three separate experiments. ${ }^{\star \star} p<0.01,{ }^{\star \star \star} p<0.001$ compared with positive control response (no $I L-4$ ).

epithelial cells expressed appreciable amounts of iNOS, always at the superficial part of the crypt and the surface of the mucosa, while no other positive cells were found in the lamina propria (fig 1B). iNOS was characteristically expressed in most cases at the apical part of the epithelial cells and was in close association with neutrophil infiltration of the lamina propria (fig 1C). Similar results were seen in all cases of infectious colitis examined (fig 1D). Colonic
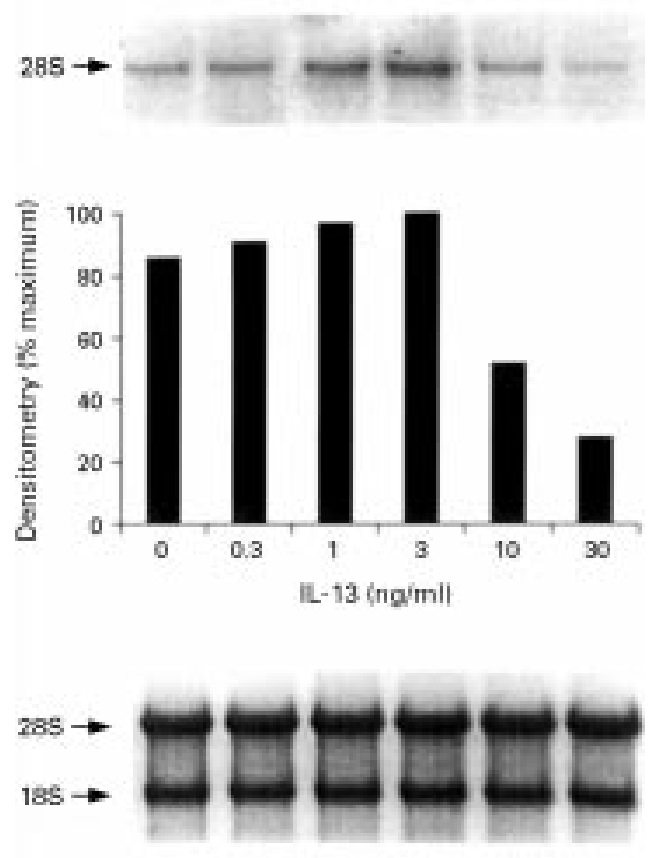

Figure 5 Inducible nitric oxide synthase (iNOS) $m R N A$ expression by HT-29 cells after treatment with interleukin expression by HT-29 cells after treatment with inter
(IL) $-1 a(10 \mathrm{ng} / \mathrm{ml}) /$ interferon $\gamma($ IFN- $\gamma)(300$ $\mathrm{U} / \mathrm{ml}) /$ tumour necrosis factor a $(T N F-a)(100 \mathrm{ng} / \mathrm{ml})$ in the presence of increasing concentrations of IL-13. The proinflammatory cytokines were added after one hour of pretreatment with IL-13 and incubated for 12 hours at $37^{\circ} \mathrm{C}$. The top panel is the northern blot, the middle panel is the densitometry analysis of the blot, and the bottom panel the ethidium bromide stained $18 S$ and $28 S$ bands indicating equal loading of the lanes. This is a representative of three experiments. 

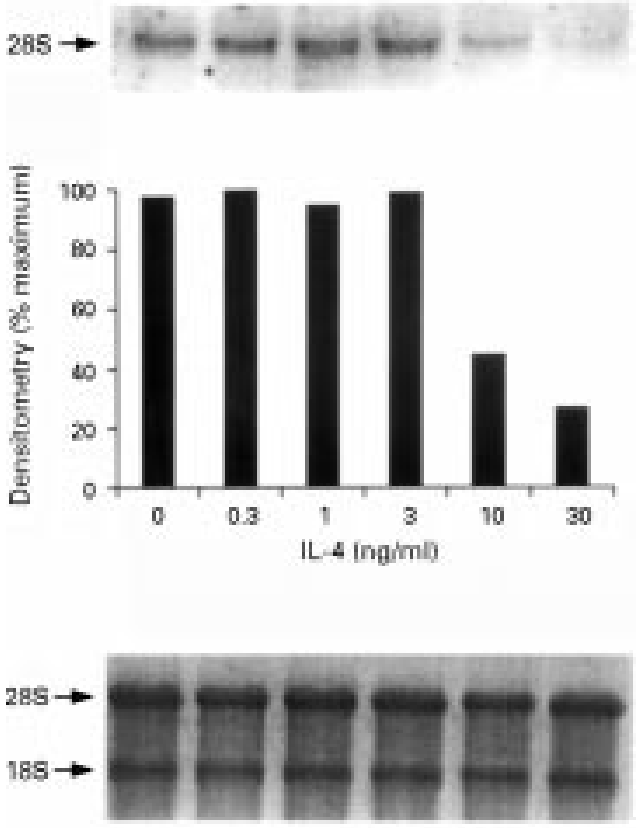

Figure 6 Inducible nitric oxide synthase (iNOS) $m R N A$ expression by HT-29 cells after treatment with interleukin (IL)-1a $(10 \mathrm{ng} / \mathrm{ml})$ /interferon $\gamma(I F N-\gamma)(300$

$\mathrm{U} / \mathrm{ml}) /$ tumour necrosis factor $(T N F-\alpha)(100 \mathrm{ng} / \mathrm{ml})$ in the presence of increasing concentrations of IL-4. The proinflammatory cytokines were added after one hour of pretreatment with IL-4 and incubated for 12 hours at

$37^{\circ} \mathrm{C}$. The top panel is the northern blot, the middle panel is the densitometry analysis of the blot, and the bottom panel the ethidium bromide stained $18 S$ and $28 S$ bands indicating equal loading of the lanes. This is a representative of three experiments.

biopsy specimens from patients with infectious colitis, which stained positive for iNOS in the acute phase of the disease, when re-examined when the patients were in total remission did not express detectable iNOS (fig 1E). No staining was seen in the negative controls, when the primary antibody (NO-53) was omitted, and staining was dramatically reduced when NO-53 was incubated with the immunogenic peptide (described above) (fig $1 \mathrm{~F}$ ).

\section{NOS ACTIVITY}

Resting HT-29 cells were found to produce a basal amount of nitrite (fig 2), which was due to constitutive NOS as no iNOS expression was detected and the production of basal nitrite was unaffected by the protein synthesis inhibitor cycloheximide. None of the cytokines, added alone, was found to affect this constitutive nitrite generation by HT-29 cells. The minimal requirement for a significant increase in nitrite generation was the combination IL- $1 \alpha / \mathrm{IFN}-\gamma$ (all other pairs of cytokines were ineffective), and the addition of TNF- $\alpha$ to this combination induced a threefold enhancement of nitrite production (fig 2). Similarly, stimulation of HT-29 cells with IL-13, IL-4, or IL-10 for up to 48 hours did not affect constitutive nitrite generation by these cells (fig 2). Pretreatment of HT-29 cells with different concentrations of IL-13 or IL-4 $(0.3-30 \mathrm{ng} / \mathrm{ml})$ for one hour before the addition of the optimal cytokine cocktail (IL- $1 \alpha / \mathrm{TNF}-\alpha / \mathrm{IFN}-\gamma$ ) pro-
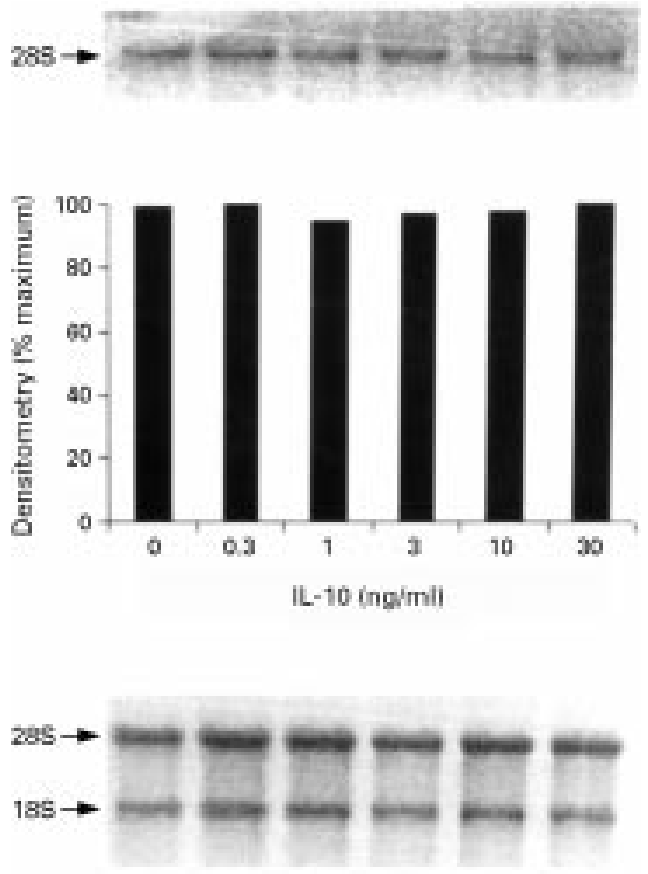

Figure 7 Inducible nitric oxide synthase (iNOS) $m R N A$ expression by HT-29 cells after treatment with interleukin (IL) $-1 a(10 \mathrm{ng} / \mathrm{ml})$ /interferon $\gamma(I F N-\gamma)(300$

$\mathrm{U} / \mathrm{ml}) /$ tumour necrosis factor a (TNF-a) $(100 \mathrm{ng} / \mathrm{ml})$ in the presence of increasing concentrations of IL-10. The proinflammatory cytokines were added after one hour of pretreatment with IL-10 and incubated for 12 hours at $37^{\circ} \mathrm{C}$. The top panel is the northern blot, the middle panel is the densitometry analysis of the blot, and the bottom panel the ethidium bromide stained $18 S$ and $28 S$ bands indicating equal loading of the lanes. This is a representative of three experiments.

duced a concentration related and highly significant $(p<0.001)$ inhibition of nitrite generation (figs 3 and 4 respectively), with about $50 \%$ inhibition at $3 \mathrm{ng} / \mathrm{ml}$ either IL-13 or IL-4. Finally, we found that IL-10 over the concentration range $0.3-30 \mathrm{ng} / \mathrm{ml}$ had no effect on IL- $1 \alpha / \mathrm{TNF}-\alpha / \mathrm{IFN}-\gamma$ induced nitrite generation by HT-29 cells (data not shown).

INOS MRNA EXPRESSION BY HT-29 CELLS

In unstimulated cells or after stimulation with IL-13, IL-4, or IL-10, no iNOS transcripts were detected. To determine the effect of IL-13, IL-4, and IL-10 on cytokine induced iNOS mRNA expression, cells were pretreated for one hour with different concentrations $(0.3-30 \mathrm{ng} / \mathrm{ml})$ of IL-13, IL-4, or IL-10, then IL-1 $\alpha(10 \mathrm{ng} / \mathrm{ml}) / \mathrm{IFN}-\gamma(300 \mathrm{U} / \mathrm{ml}) / \mathrm{TNF}-\alpha$ $(100 \mathrm{ng} / \mathrm{ml})$ was added, and iNOS mRNA expression was measured at 12 hours. Low concentrations $(0.3-3 \mathrm{ng} / \mathrm{ml})$ of both IL-13 and IL- 4 had no significant effect on IL-1 $\alpha$ / IFN- $\gamma /$ TNF- $\alpha$ induced iNOS mRNA expression, whereas higher concentrations $(>10$ $\mathrm{ng} / \mathrm{ml}$ ) of both IL-13 and IL-4 significantly suppressed iNOS mRNA expression by HT-29 cells (figs 5 and 6 respectively). We have previously shown that the minimal requirement for the induction of iNOS mRNA is IL- $1 \alpha$ and IFN- $\gamma$, while the addition of TNF- $\alpha$ to this combination produces an up regulation of nitrite production without a further increase in iNOS mRNA. ${ }^{13}$ These data taken together 


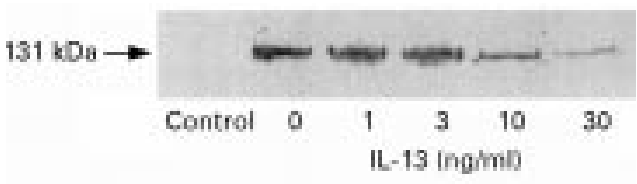

Figure 8 Inducible nitric oxide synthase (iNOS) protein expression by HT-29 cells after stimulation with interleukin (IL) $-1 a(10 \mathrm{ng} / \mathrm{ml})$ /interferon $\gamma($ IFN- $\gamma)(300$ $\mathrm{U} / \mathrm{ml}) /$ tumour necrosis factor a (TNF-a) $(100 \mathrm{ng} / \mathrm{ml})$ in the presence of increasing concentrations of IL-13. HT-29 cells were pretreated for one hour with $I L-13$, then proinflammatory cytokines were added. HT-29 monolayers were scraped after 24 hours incubation at $37^{\circ} \mathrm{C}$ and total protein was extracted. iNOS protein expression was determined by western blot analysis, using an anti-human iNOS antibody. This is a representative of three experiments.

suggest that IL-13 and IL-4, at low concentrations $(0.3-3 \mathrm{ng} / \mathrm{ml})$, down regulate the posttranscriptional effect of TNF- $\alpha$ on the IL- $1 \alpha /$ IFN $-\gamma$ induced nitrite generation by HT-29 cells, while high concentrations of IL-13 and IL-4 (>10 ng/ml) additionally block the transcription of iNOS mRNA induced by the proinflammatory cytokines. Finally, pretreatment with IL-10 had no effect on the IL- $1 \alpha / \mathrm{IFN}-\gamma / \mathrm{TNF}-\alpha$ induced iNOS mRNA in HT-29 cells (fig 7).

iNOS PROTEIN EXPRESSION

HT-29 cells were treated for 24 hours with the appropriate stimuli, then iNOS protein expression was determined by western blot analysis. Unstimulated cells did not express iNOS protein. The minimal requirement for iNOS protein expression was the combination IL-1 $\alpha /$ IFN- $\gamma$, and iNOS protein expression was greatly enhanced by the addition of $\mathrm{TNF}-\alpha$ to this combination (data not shown), in parallel with the threefold increase in nitrite generation (fig 2). To determine the effect of IL-13 on cytokine induced iNOS protein expression, HT-29 cells were pretreated for one hour with different concentrations of IL-13 (0.3-30 $\mathrm{ng} / \mathrm{ml}$ ) before stimulation with the optimal cytokine cocktail of IL- $1 \alpha / \mathrm{IFN}-\gamma / \mathrm{TNF}-\alpha$. IL-13 was found to produce a concentration dependent inhibition of iNOS protein expression induced by IL- $1 \alpha / \mathrm{IFN}-\gamma / \mathrm{TNF}-\alpha$ (fig 8 ), similar to the inhibition of IL- $1 \alpha / \mathrm{IFN}-\gamma /$ $\mathrm{TNF}-\alpha$ induced nitrite generation (fig 3).

\section{Discussion}

We have shown iNOS protein expression by immunohistochemistry in epithelial cells of the inflamed colonic mucosa of patients with active UC and infectious colitis. iNOS protein expression was not detected in the mucosa of biopsy samples from patients with infectious colitis in remission, uninvolved mucosa of colon adenocarcinoma, diverticular disease, or healthy individuals. iNOS was strongly expressed on the apical surface of the epithelium at the top of the crypts with less expression in deeper epithelial cells of the crypts, and was not detectable in the lamina propria or in the inflammatory leucocytes closely associated with the epithelial cells. These results strongly suggest that the colonic epithelial cells are the major source of $\mathrm{NO}$ production and increased iNOS activity in the mucosa from patients with
$\mathrm{UC},{ }^{10-12}$ and this NO generation is in close association with, and may contribute to, the inflammatory process. Our results with biopsy samples from patients with newly diagnosed UC and infectious colitis extend and complement a parallel study by Singer $e t a l{ }^{30}$ in which resected colon from patients with long standing intractable UC were examined, and showed similar heavy iNOS staining in the apical region of crypts in close association with areas of intense neutrophil infiltration of the lamina propria and epithelium. In addition, in the cases that expressed iNOS, Singer et $a l^{30}$ have noted that nitrotyrosine, the stable product of the action of peroxynitrite on tyrosinecontaining proteins, was also localised in colonic epithelial cells in areas of inflammation, in both the surface epithelium and crypts. $^{30}$ These findings suggest that some component of the inflammatory response induces iNOS expression in colonic epithelial cells and that NO generated by these cells reacts with superoxide to produce peroxynitrite, which nitrates cellular proteins and forms nitrotyrosine. Aminosalicylates, which are widely used to treat IBD, inhibit these nitrosation reactions ${ }^{34}$; this activity may account for their therapeutic effects in intestinal inflammation.

The functional role of $\mathrm{NO}$ production by colonic epithelial cells is not known, and it is not clear whether the increased NO production in patients with IBD is beneficial or harmful to the tissue. Although NO, or the subsequent reactive products, can contribute to the cytopathology of host cells when produced in excess, ${ }^{35}$ some data suggest that $\mathrm{NO}$ may diminish epithelial damage. NO can scavenge oxygen radicals reducing their harmful effects, ${ }^{36}$ and inhibition of NO synthesis promotes damage induced by $\mathrm{HCl}$, ethanol, and lipopolysaccharide, ${ }^{37-39}$ suggesting that NO may have a protective effect on the gut. In addition, epithelial iNOS expression may provide an oxidative barrier to bacterial invasion. ${ }^{40}$ On the other hand, enhanced NO release by the induction of iNOS in the colon may contribute directly to the mucosal damage caused by a variety of mechanisms including inhibition of DNA synthesis, inhibition of mitochondrial function, and intracellular iron release. ${ }^{41}{ }^{42} \mathrm{NO}$ freely interacts with oxygen metabolites to yield nitrosating species, and the formation of carcinogenic nitrosamines may be the link with the increased frequency of colorectal cancer in UC. ${ }^{43}$ High levels of nitrosamines have been shown in rectal dialysates of patients with active IBD. ${ }^{44}$ We showed that unstimulated HT-29 colonic epithelial cells produced a basal amount of constitutive NO, while stimulation with cytokines induced a large amount of NO as the result of iNOS expression. It is possible that small amounts of NO produced in colonic epithelial cells by constitutive NOS may preserve intestinal integrity, whereas the large amounts of NO produced as the result of iNOS induction have a proinflammatory effect causing tissue injury.

Both $\mathrm{T}$ cells and $\mathrm{T}$ cell derived cytokines including IFN- $\gamma$, IL-4, IL-13, and IL-10 have 
been detected in the mucosa of patients with IBD, ${ }^{1425} 4546$ and it has been proposed that this may be associated with the pathogenesis of the disease. ${ }^{27}$ We have used the human colonic epithelial cell line HT-29 as a model to explore the regulation by $\mathrm{T}$ cell derived cytokines of epithelial iNOS expression and activity. We have now shown that IL-4 and IL-13, but not IL-10, produce a concentration dependent inhibition of the nitrite generation and iNOS protein and mRNA expression induced in colonic epithelial cells by the cytokine cocktail of IL- $1 \alpha / \mathrm{IFN}-\gamma / \mathrm{TNF}-\alpha$. The inhibitory effect of IL-13 and IL-4 observed at low concentrations of each of these cytokines is dependent on the presence of TNF- $\alpha$, acting as a posttranscriptional stimulator of iNOS expression and activity. However, at higher concentrations, IL- 4 and IL-13 are potent inhibitors of iNOS mRNA induction, which is entirely independent of the presence of TNF- $\alpha$. IL-13 has been shown to inhibit NO production by activated macrophages in animals. ${ }^{47}{ }^{48}$ Saura et $a l^{49}$ have shown that IL-13 inhibits iNOS expression in human mesangial cells after stimulation with a cocktail of proinflammatory cytokines and lipopolysaccharide. IL-10 has been found to inhibit NO production by mouse activated macrophages. ${ }^{50} 51$ In contrast, we found that IL-10 had no effect on proinflammatory cytokine induced iNOS expression and activity by colonic epithelial cells. Similarly, IL-10 had no effect on IL-8 generation by HT-29 cells, unlike IL-13. ${ }^{52}$ There is increasing evidence to suggest that IL-10, because of its ability to inhibit monocyte/macrophage activation, may be a useful treatment of IBD..$^{534}$ However, the results presented here suggest that IL-13 may be a more appropriate T lymphocyte derived cytokine to use because of its ability to inhibit epithelial cell iNOS expression as well as its ability to inhibit monocyte/ macrophage activation..$^{15} 165556$

In active colitis it is likely that the optimal cocktail of cytokines for induction of iNOS activity is present. Strategies to increase apical epithelial concentrations of IL-4 and/or IL-13 or to regulate the signal transduction system responsible for the inhibitory effect of these cytokines on iNOS transcription and protein expression may reveal novel targets for therapeutic intervention in IBD. Whether the inhibition of $\mathrm{NO}$ production will be of therapeutic value in intestinal inflammation awaits further investigation of NOS isoforms, and probably the development of selective NOS inhibitors to inhibit the excessive NO production by iNOS without changing the physiological control of vascular tone and cellular integrity by the constitutive enzyme. ${ }^{9}$

We would like to thank Mrs Carolyn F Male, FIMBS, for her technical assistance in the Histopathology Department, Royal United Hospital, Bath. This work was supported by the Astra Foundation, UK, the National Association for Colitis and Crohn's Disease (NACC), UK, the Wellcome Trust, UK, and the Hellenic Society of Gastroenterology, Greece.

1 Moncada S, Higgs A. The L-arginine-nitric oxide pathway $N$ Engl f Med 1993;329:2002-12.

2 Nathan C, Qiao-wen X. Nitric oxide synthases: roles, tolls, and controls. Cell 1994;78:915-8. 3 Michel T, Li GK, Busconi L. Phosphorylation and subcellular translocation of endothelial nitric
thase. Proc Natl Acad Sci USA 1993;90:252-6.

4 Nathan C. Nitric oxide as a secretory product of mammalian cells. FASEB f 1992;6:3051-64.

5 Nakane M, Schmidt HHHW, Pollock JS, et al. Cloned human brain nitric oxide synthase is highly expressed in skeletal muscle. FEBS Lett 1993;316:175-80

6 Moncada S, Palmer RMJ, Higgs EA. Nitric oxide: physiology, pathophysiology and pharmacology. Pharmacol Rev 1991;43:109-42.

7 Nussler AK, Billiar TR. Inflammation, immunoregulation, and inducible nitric oxide synthase. F Leukoc Biol 1993;54: 171-8.

8 Morris SM, Billiar TR. New insights into the regulation of inducible nitric oxide synthase. Am $\mathcal{F}$ Physiol 1994;266: E829-39.

9 Whittle BJR. Nitric oxide in gastrointestinal physiology and pathology. In: Johnson LR, ed. Physiology of the gastrointestial tract. 3rd ed. New York: Raven Press, 1994.267-94.

10 Middleton SJ, Shorthouse M, Hunter JO. Increased nitric oxide synthesis in ulcerative colitis. Lancet 1993;341:465-6.

11 Lundberg JON, Hellstrom PM, Lundberg JM, et al. Greatly increased luminal nitric oxide in ulcerative colitis. Lancet 1994;344:1673-4

12 Boughton-Smith NK, Evans SM, Hawkey CJ, et al. Nitric oxide synthase activity in ulcerative colitis and Crohn's disease. Lancet 1993;342:338-40.

13 Kolios G, Brown Z, Robson RL, et al. Inducible nitric oxide synthase activity and expression in a human colonic epithelial cell line, HT-29. Br f Pharmacol 1995;116:2866-72.

14 Sartor RB. Cytokines in intestinal inflammation: pathophysiological and clinical considerations. Gastroenterology 1994;106:533-9.

15 Minty A, Chalon P, Derocq J-M, et al. Interleukin-13 is a new human lymphokine regulating inflammatory and new human lymphokine regulating inflam

16 Zurawski G, De Vries JE. Interleukin 13, an interleukin 4-like cytokine that acts on monocytes and B cells, but not on T cells. Immunol Today 1994;15:19-26.

17 Marfaing-Koka A, Devergne O, Gorgone G, et al. Regulation of the production of the RANTES chemokine by endothelial cells: synergistic induction by IFN-gamma plus TNF- $\alpha$ and inhibition by IL- 4 and IL-13. F Immunol 1995; 154:1870-8.

18 de Waal Malfyt R, Abrams J, Bennett B, et al. Interleukin 10 (IL-10) inhibits cytokine synthesis by human monocytes: an autoregulatory role of IL-10 produced by monocytes. $\mathcal{F}$ Exp Med 1991;174:1209-20.

19 Moore KW, O'Garra A, De Waal Malefyt R, et al. Interleukin-10. Anпu Rev Immunol 1993;11:165-90.

20 Kasama T, Strieter RM, Lukacs NW, et al. Regulation of neutrophil-derived chemokine expression by IL-10. $\mathcal{F}$ Immunol 1994;152:3559-69.

21 Isaacs KL, Sartor RB, Haskill JS. Cytokine mRNA profiles in inflammatory bowel disease mucosa detected by PCR amplification. Gastroenterology 1992;103:1587-95.

22 Niessner M, Volk BA. Altered Th1/Th2 cytokine profiles in the intestinal mucosa of patients with inflammatory bowel disease as assessed by quantitative reversed transcribed polymerase chain reaction (RT-PCR). Clin Exp Immunol 1995;101:428-35.

23 Kucharzik T, Stoll R, Lugering N, et al. Circulating antiinflammatory cytokine IL-10 in patients with inflammatory bowel disease (IBD). Clin Exp Immunol 1995;100: $452-6$.

24 Radford-Smith D, McGowan I, Jewell DP. Th1 and Th2 gene expression in inflammatory bowel disease. Gastroenterology 1994;106: A757.

25 Radford-Smith D, Jewell DP. Cytokines and inflammatory bowel disease. Baillieres Clin Gastroenterol 1996;10:151-64. 26 Kucharzik T, Lugering N, Weigelt $\mathrm{H}$, et al. Immunoregulatory properties of IL-13 in patients with inflammatory bowel disease; comparison with IL-4 and IL-10. Clin Exp Immunol 1996;104:483-90.

27 Kucharzik T, Lugering N, Adolf M, et al. Synergistic effect of immunoregulatory cytokines on peripheral blood monocytes from patients with inflammatory bowel disease. Dig Dis Sci 1997;42:805-12.

28 Kahn R, Lohler J, Rennick D, et al. Interleukin-10-deficient mice develop chronic enterocolitis. Cell 1993;75:263-74.

29 Rennick DM, Fort MM, Davidson NJ. Studies with IL-10 deficient mice: an overview. F Leukoc Biol 1997;61:389-96.

30 Singer II, Kawka DW, Scott S, et al. Expression of inducible nitric oxide synthase and nitrotyrosine in colonic epithelium in inflammatory bowel disease. Gastroenterology 1996; 111:871-85.

31 Misko TP, Schilling RJ, Salvemini D, et al. A flourometric assay for the measurement of nitrite in biological samples. Anal Biochem 1993;214:11-16.

32 Strieter RM, Kunkel SL, Showell HJ, et al. Endothelial cell gene expression of a neutrophil chemotactic factor by TNF- $\alpha$, LPS and IL-1 $\beta$. Science 1989;243:1467-9.

33 Laemmli UK. Cleavage of structural proteins during the assembly of the head of bacteriophage T4. Nature $1970 ; 227: 680-5$

34 Grisham MB, Miles AM. Effects of aminosalicylates and immunosuppressive agents on nitric oxide-dependent
N-nitrosation reactions. Biochem Pharmacol 1994;47:1897902 .

35 Tepperman BL, Brown JF, Korolkiewicz R, et al. Nitric oxide synthase activity, viability and cyclic GMP levels in
rat colonic epithelial cells: effect of endotoxin challenge. $\mathcal{F}$ Pharmacol Exp Ther 1994;271:1477-82. 
36 Grisham MB. Oxidants and free radicals in inflammatory bowel disease. Lancet 1994;344:859-61.

37 Kitagawa H, Takeda F, Kohei H. Effect of endothelium derived relaxing factor on the gastric lesion induced by $\mathrm{HCl}$ in rats. F Pharmacol Exp Ther 1990;253:1133-7.

38 MacNaughton WK, Cirino G, Wallace JL. Endothelium relaxing factor (nitric oxide) has protective actions in the relaxing factor (nitric oxide) has pro
stomach. Life Sci 1989;4589:1869-76.

39 Hutcheson I, Whittle BJR, Boughton-Smith NK. Role of nitric oxide in maintaining vascular integrity in endotoxininduced acute intestinal damage in the rat. $\mathrm{Br} \mathcal{F}$ Pharmacol 1990;101:815-20.

40 Hartley MG, Hudson MJ, Swarbrick ET, et al. The rectal mucosa-associated microflora in patients with ulcerative colitis. F Med Microbiol 1992;36:96-103.

41 Kwon NS, Stuehr DJ, Nathan CF. Inhibition of tumour cell ribonucleotide reductase by macrophage-derived nitric oxide. F Exp Med 1991;174:761-7.

42 Drapier JC, Hibbs JB. Murine cytotoxic activated macrophages inhibit aconitase in tumour cells. Inhibition involves the iron-sulfur prosthetic group and is reversible. 7 Clin Invest 1986;78:790-7.

43 Grisham MB, Ware K, Gilleland HE, et al. Neutrophilmediated nitrosamine formation: a role of nitric oxide in rats. Gastroenterology 1992;103:1260-6.

44 MacNaughton WK. Nitric oxide-donating compounds stimulate electrolyte transport in the guinea pig intestine in stimulate electrolyte transport
vitro. Life Sci 1993;53:585-93.

45 Lichtman SN, Sartor RB. Examining the role of inflammatory cytokines in chronic inflammatory bowel disease. $f$ Pediatr Gastroenterol Nutr 1993;16:239-40.

46 Kolios G, Nakos A. Cytokines in inflammatory bowel disease. Hellenic fournal of Gastroenterology 1995;8 $117-25$.
47 Doyle AG, Herbein G, Montaner LJ, et al. Interleukin-13 alters the activation state of murine macrophages in vitro: alters the activation state of murine macrophages in vitro: Immunol 1994;24:1441-5.

48 Doherty TM, Kastelein R, Menon S, et al. Modulation of murine macrophage function by IL-13. F Immunol 1993;151:7151-60.

49 Saura M, Martinez-Dalmau R, Minty A, et al. Interleukin-13 inhibits inducible nitric oxide expression in human mesangial cells. Biochem f 1996;313:641-6.

50 Oswald IP, Gazzinelli RT, Sher A, et al. IL-10 synergizes with IL-4 and transforming growth factor beta to inhibit macrophage cytotoxic activity. F Immunol 1992;148:357882 .

51 Cenci E, Romani L, Mencacci A, et al. Interleukin-4 and interleukin-10 inhibit nitric oxide-dependent macrophage killing of candida-albicans. Eur F Immunol 1993;23:1034-8.

52 Kolios G, Robertson DAF, Jordan NJ, et al. Interleukin-8 production by the human colon epithelial cell line HT-29: production by the human colon epithelial cell line HT-29: 351-9.

53 Schreiber S, Heinig T, Thiele H-G, et al. Immunoregulatory role of interleukin 10 in patients with inflammatory bowel disease. Gastroenterology 1995;108:1434-44

54 Duchmann R, Schmitt E, Knolle P, et al. Tolerance towards resident intestinal flora in mice is abrogated in experimental colitis and restored by treatment with interleukin-10 or antibodies to interleukin-12. Eur f Immunol 1996;26:934-8.

55 McKenzie ANJ, Culpepper JA, De Waal Malefyt R, et al. Interleukin-13, a T-cell-derived cytokine that regulates human monocyte and B-cell function. Proc Natl Acad Sci USA 1993;90:3735-9.

56 De Waal Malefyt R, Figdor CG, Huijbens R, et al. Effects of IL-13 on phenotype, cytokine production, and cytotoxic function of human monocytes: comparison with IL-4 and modulation by IFN-gamma or IL-10. F Immunol 1993;151: $6370-81$. 